\title{
Autoantibodies against human insulin
}

\author{
TERENCE J WILKIN, SARAH NICHOLSON
}

\begin{abstract}
Sera from 680 non-diabetic subjects with suspected autoimmune disease were screened for 13 different antibodies. Of the 582 sera found to contain these antibodies, nine bound insulin in an IgG specific enzyme linked immunosorbent assay (micro ELISA). Four of the sera bound human, porcine, and bovine insulins and five bound exclusively human insulin. "Cold" human, porcine, and bovine insulins each displaced, in a dose dependent manner, the four sera which bound all three insulins, but only human insulin displaced the remaining five, porcine and bovine insulins having little or no effect in concentrations up to $1000 \mathrm{U} / 1$.

These observations point to the existence of autoantibodies specifically against human insulin in some subjects with established autoimmunity.
\end{abstract}

\section{Introduction}

Over the past 20 years numerous reports claim to have identified autoantibodies against insulin, ${ }^{1-4}$ but in most either the specificity of the assay, the exact nature of the binding factor, or insulin naivety in the subjects has been in doubt. ${ }^{5}$ While the antibodies against commercial insulin commonly found in the sera of diabetics are usually of minor clinical importance, those arising spontaneously might be of greater potential interest as markers for autoimmunity, analogous to the thyroglobulin antibodies in thyroiditis and antibodies against intrinsic factor in gastritis. Autoimmune disorders tend to cluster within individuals, ${ }^{6}$ so that the search for insulin autoantibodies might

\footnotetext{
Department of Medicine II, General Hospital, Southampton SO9 4XY

TERENCE J WILKIN, MD, MRCP, Wellcome senior lecturer in endocrinology

SARAH NICHOLSON, technical assistant

Correspondence to: Dr Terence J Wilkin.
}

logically be concentrated on people already subject to autoimmunity. We have therefore looked for antibodies against insulin in the sera of a large number of patients with autoimmune diathesis.

\section{Subjects and methods}

We examined sera from 680 consecutive non-diabetic patients (238 men, 442 women; mean age 53 (SD 28) years) with suspected autoimmune disease referred to the autoimmune profile laboratory in our department. Tests included in the profile were for antibodies against thyroid microsomes, thyroglobulin, gastric parietal cells, renal glomerular basement membrane, striated muscle, smooth muscle, mitochondria, reticulin, keratin, nuclear factor, DNA, skin, and rheumatoid factor. Based on the results the patients were divided into 582 subjects who were found to have one or more of these antibodies (group 1) and 98 subjects found not to have any of them (group 2). We also studied the sera from a control group of 94 healthy adults (mean age 38 (SD 7) years) with no history or suspicion of autoimmune disease (group 3), 31 randomly selected non-insulin dependent diabetics (mean age 64 (SD 11) years), and 19 insulin dependent diabetics (mean age 57 (SD 17) years).

\section{ASSAY}

We devised an enzyme linked immunosorbent microassay ${ }^{7}$ similar to the system for measuring thyroglobulin antibodies. ${ }^{8}$ Briefly, test serum diluted $1 / 10$ in phosphate buffered saline $(\mathrm{pH} \mathrm{7 \cdot 2)}$ was incubated in a polystyrene microtitre plate (Kontron Analytical, St Albans) precoated with pure human, pork, or bovine monocomponent insulin crystals (Novo Research Institute, Copenhagen) in carbonatebicarbonate buffer, $\mathrm{pH} 9 \cdot 6$. The reaction was measured on a spectrophotometer (Dynatech MR 580 Micro Plate Reader) after adding antihuman IgG (Dakopatts, Mercia Brocades Ltd, Weybridge) conjugated to horseradish peroxidase (Sigma Chemicals, Poole), which produced a quantitative colour change (absorption) in the substrate, $o$-phenylene diamine (Sigma Chemicals). The assay was thus a solid phase binding system specific for IgG antibodies. The interassay coefficient of variance (mean/standard deviation $\times 100$ ) was less than $10 \%$ for all three insulins at widely spaced points on the reference curves, and the reaction was shown to be specific for insulin. Antibodies against pure human (Eli Lilly Company, Indianapolis) and pork and bovine (Novo Research Institute) $C$ peptide were measured in a similar microassay. 
Results were derived from the reference curve for the appropriate species of insulin, obtained from serial dilutions of the diabetic serum containing the highest antibody titre encountered in this laboratory, and incorporated into the microtitre plate. Each result is a dilution equivalent-that is, the percentage dilution of the reference serum $(100 \%=1 / 10)$ giving the same colour change as the test serum diluted $1 / 10$

\section{Results}

\section{BINDING STUDIES}

Reference curves and controls (fig 1)-Mean binding of human monocomponent insulin by the 94 controls (group 3) was 0.054 (SD 0.021) absorption unit, giving a range of 0.012 to 0.096 , equivalen to a less than $5 \%$ dilution of the reference serum. A pool of 20 norma sera (10 male, 10 female) gave a binding of 0.052 absorption unit,

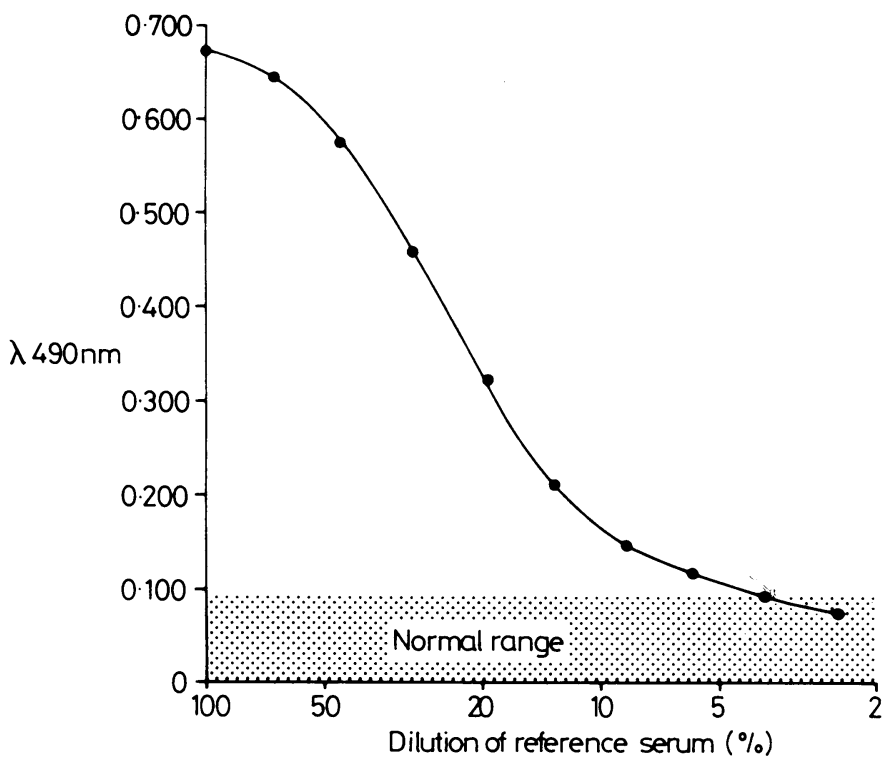

FIG 1 -Reference curve for human insulin (from insulin dependent diabetic $D_{1}$ in table II) expressed as percentage dilution $(100 \%=1 / 10)$. (Normal range (stippled area) derived from values in 94 healthy adults.)

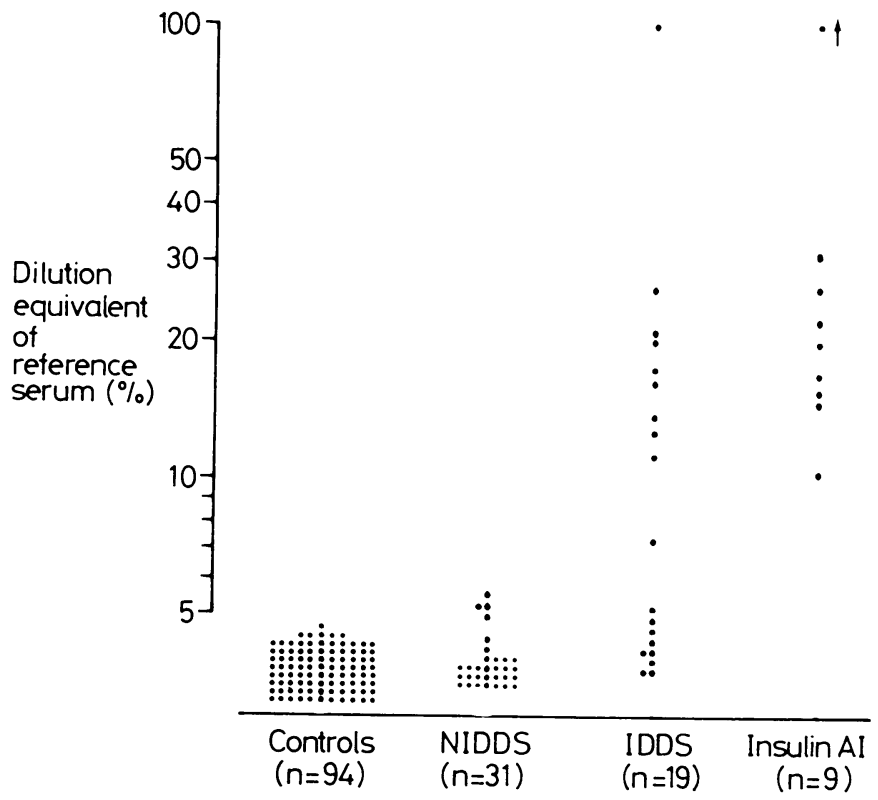

FIG 2-Insulin binding capacities (percentage dilution equivalent of reference serum) of control subjects, non-insulin dependent diabetics (NIDDS), insulin dependent diabetics (IDDS), and subjects with insulin autoimmunity (AI).

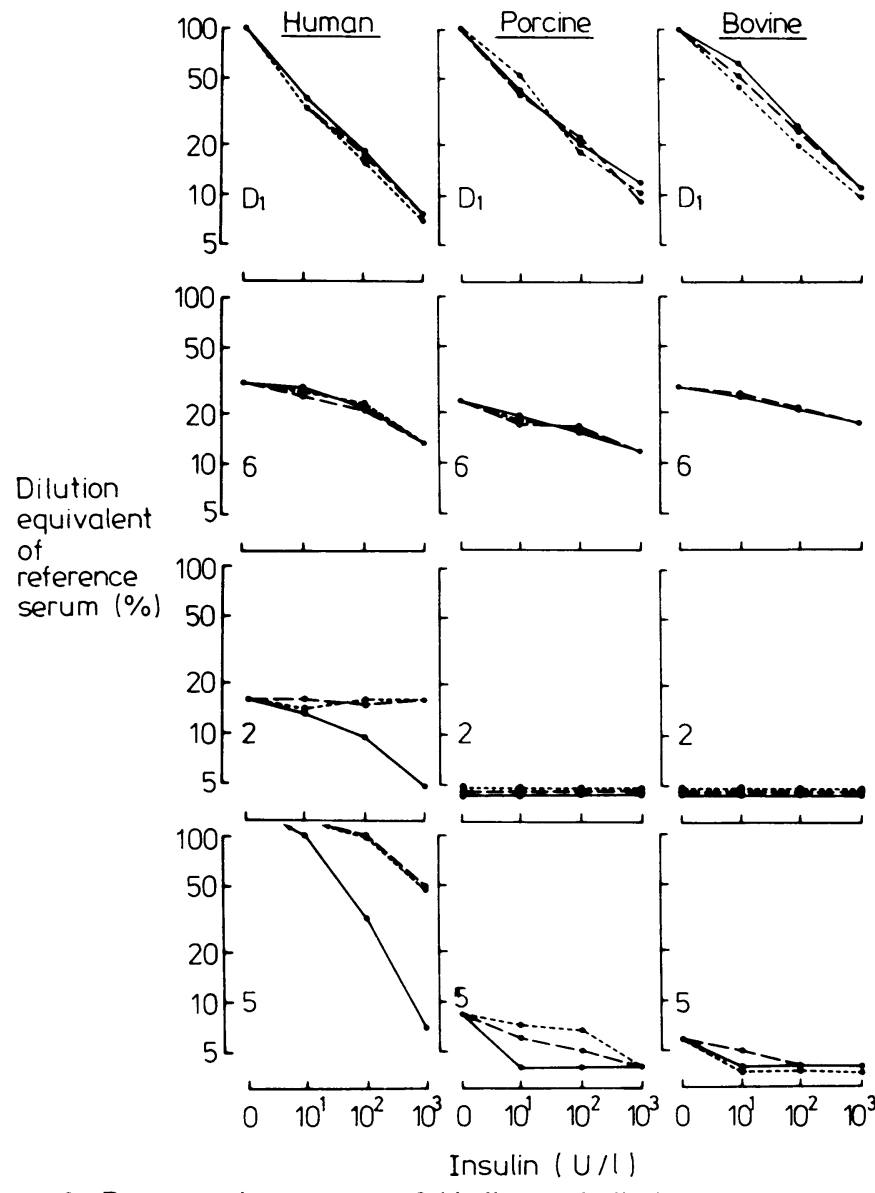

FIG 3-Representative patterns of binding and displacement behaviour displayed by diabetic serum (from subject $D_{1}$ ), non-specific insulin autoimmune serum (from case 6), human insulin specific autoimmune serum (from case 2), and incompletely human insulin specific autoimmune serum (from case 5). Left hand column: binding was to human insulin. Middle column: binding was to porcine insulin. Right hand column: binding was to bovine insulin. - Human insulin added in displacement studies. ... - Porcine insulin added in displacement studies. . . . Bovine insulin added in displacement studies.

equivalent to less than $2 \%$. Corresponding results using pork and bovine monocomponent insulins were similar.

Diabetics-Figure 2 shows the results of insulin binding by sera from the non-insulin dependent and insulin dependent diabetics. Binding was less than $5 \%$ in 28 of the 31 non-insulin dependent diabetics and less than $6 \%$ in all of them. Of the 19 insulin dependent diabetics, 11 showed binding greater than $5 \%$, the strongest $(100 \%)$ providing the reference serum for all assays.

Patients tested for autoimmune profile-None of the sera from patients with a negative autoimmune profile (group 2) bound insulin, whereas sera from nine of the 582 patients in group $1(1.5 \%)$ did bind insulin (fig 2). None of these nine was a known diabetic and so far as we and their general practitioners knew none had received insulin.

When the binding studies were repeated after separation of gammaglobulins by precipitation with ammonium sulphate all the insulin binding activity resided in the gammaglobulin fraction and none in the supernatant. Antibodies against $C$ peptide were found only in sera from the insulin treated diabetics and were restricted to bovine C peptide.

In order to check whether any particular autoantibody in the autoimmune profile was causing false positive results for insulin binding we checked on the relation between the distribution of antibodies tested in the profile and that in our nine patients. The relation was random (table I)

Four of the nine insulin binding sera (from cases 6-9) bound all three species of insulin, while five of them (from cases 1-5) bound exclusively, or virtually exclusively, human monocomponent insulin (table II). Thus serum from case 2 bound human insulin but showed no avidity for porcine and bovine insulins. Serum from case 5 bound human insulin more strongly than the laboratory reference serum but had only very weak avidity for porcine and bovine insulins. 
TABLE I-Distribution of autoantibodies in sera of nine subjects positive for insulin autoantibody

\begin{tabular}{|c|c|c|c|c|c|c|c|}
\hline Case No & Thyroid microsomes & Gastric parietal cells & Striated muscle & Smooth muscle & Antinuclear factor & Rheumatoid factor & DNA \\
\hline 1 & \multirow{7}{*}{+} & + & \multirow{7}{*}{+} & & + & & \multirow{7}{*}{$\begin{array}{l}+ \\
+\end{array}$} \\
\hline $\begin{array}{l}2 \\
3\end{array}$ & & + & & + & + & 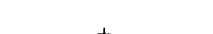 & \\
\hline $\begin{array}{l}3 \\
4\end{array}$ & & + & & + & & $\begin{array}{l}+ \\
+\end{array}$ & \\
\hline 5 & & + & & & & $r$ & \\
\hline 6 & & & & & + & + & \\
\hline $\begin{array}{l}7 \\
8\end{array}$ & & & & + & + & & \\
\hline 9 & & & & + & + & & \\
\hline
\end{tabular}

TABLE II-Results of binding and displacement studies in nine test subjects and two insulin dependent diabetic subjects $\left(D_{1}\right.$ and $\left.D_{2}\right)$. Binding expressed as $\%$ dilution of reference serum $\left(D_{1}\right)$ giving same ELIS A result. $H, P$, and $B$ refer to human, porcine, and bovine insulins as assay ligands, and $h$, $p$, and $b$ rfer to same insulins added in increasing concentration to assay mixture

\begin{tabular}{|c|c|c|c|c|c|c|c|c|c|c|c|c|c|c|}
\hline \multirow{3}{*}{ Case No } & \multirow{3}{*}{ Age and sex } & \multirow{3}{*}{$\begin{array}{l}\text { Coating } \\
\text { insulin }\end{array}$} & \multicolumn{12}{|c|}{ Concentration of "cold" insulin in assay (U/1) } \\
\hline & & & \multicolumn{4}{|c|}{$\mathrm{h}$} & \multicolumn{4}{|c|}{$\mathrm{p}$} & \multicolumn{4}{|c|}{$\mathbf{b}$} \\
\hline & & & 0 & $10^{1}$ & $10^{2}$ & $10^{3}$ & 0 & $10^{1}$ & $10^{2}$ & $10^{3}$ & 0 & $10^{1}$ & $10^{2}$ & $10^{3}$ \\
\hline 1 & $56 M$ & $\begin{array}{l}\mathrm{H} \\
\mathbf{P} \\
\mathbf{B}\end{array}$ & $\begin{array}{l}10 \cdot 2 \\
<5 \\
<5\end{array}$ & $\begin{array}{l}10 \cdot 1 \\
<5 \\
<5\end{array}$ & $\begin{aligned} & 5 \cdot 3 \\
< & 5 \\
< & 5\end{aligned}$ & $\begin{array}{l}<5 \\
<5 \\
<5\end{array}$ & $\begin{array}{l}10 \cdot 2 \\
<5 \\
<5\end{array}$ & $\begin{array}{l}11.4 \\
<5 \\
<5\end{array}$ & $\begin{array}{l}10 \cdot 2 \\
<5 \\
<5\end{array}$ & $\begin{array}{l}11 \cdot 1 \\
<5 \\
<5\end{array}$ & $\begin{array}{l}10 \cdot 2 \\
<5 \\
<5\end{array}$ & $\begin{array}{l}11 \cdot 3 \\
<5 \\
<5\end{array}$ & $\begin{array}{l}11 \cdot 4 \\
<5 \\
<5\end{array}$ & $\begin{array}{l}13 \cdot 2 \\
<5 \\
<5\end{array}$ \\
\hline 2 & $20 \mathrm{~F}$ & $\begin{array}{l}\mathrm{H} \\
\mathrm{P} \\
\mathrm{B}\end{array}$ & $\begin{array}{l}14.9 \\
<5 \\
<5\end{array}$ & $\begin{array}{l}13 \cdot 7 \\
<5 \\
<5\end{array}$ & $\begin{array}{l}10 \cdot 2 \\
<5 \\
<5\end{array}$ & $\begin{array}{l}<5 \\
<5 \\
<5\end{array}$ & $\begin{array}{l}14 \cdot 9 \\
<5 \\
<5\end{array}$ & $\begin{array}{l}14.5 \\
<5 \\
<5\end{array}$ & $\begin{array}{l}13.0 \\
<5 \\
<5\end{array}$ & $\begin{array}{l}13 \cdot 3 \\
<5 \\
<5\end{array}$ & $\begin{array}{l}14 \cdot 9 \\
<5 \\
<5\end{array}$ & $\begin{array}{l}13.9 \\
<5 \\
<5\end{array}$ & $\begin{array}{l}14 \cdot 5 \\
<5 \\
<5\end{array}$ & $\begin{array}{l}15 \cdot 1 \\
<5 \\
<5\end{array}$ \\
\hline 3 & $62 M$ & $\begin{array}{l}\mathrm{H} \\
\mathbf{P} \\
\mathrm{B}\end{array}$ & $\begin{array}{l}16 \cdot 7 \\
<5 \\
<5\end{array}$ & $\begin{array}{l}16 \cdot 2 \\
<5 \\
<5\end{array}$ & $\begin{array}{l}15 \cdot 6 \\
<5 \\
<5\end{array}$ & $\begin{array}{l}10 \cdot 5 \\
<5 \\
<5\end{array}$ & $\begin{array}{l}16 \cdot 7 \\
<5 \\
<5\end{array}$ & $\begin{array}{l}16 \cdot 4 \\
<5 \\
<5\end{array}$ & $\begin{array}{l}16 \cdot 1 \\
<5 \\
<5\end{array}$ & $\begin{array}{l}16 \cdot 1 \\
<5 \\
<5\end{array}$ & $\begin{array}{l}16 \cdot 7 \\
<5 \\
<5\end{array}$ & $\begin{array}{l}16 \cdot 1 \\
<5 \\
<5\end{array}$ & $\begin{array}{l}16 \cdot 7 \\
<5 \\
<5\end{array}$ & $\begin{array}{l}18.5 \\
<5 \\
<5\end{array}$ \\
\hline 4 & $60 \mathrm{M}$ & $\begin{array}{l}\mathrm{H} \\
\mathrm{P} \\
\mathrm{B}\end{array}$ & $\begin{array}{r}22 \cdot 2 \\
9 \cdot 1 \\
8.6\end{array}$ & $\begin{array}{r}24.9 \\
9 \cdot 2 \\
10.0\end{array}$ & $\begin{array}{r}24 \cdot 2 \\
9 \cdot 4 \\
10 \cdot 8\end{array}$ & $\begin{array}{r}18.5 \\
9.8 \\
10.9\end{array}$ & $\begin{array}{r}22 \cdot 2 \\
9 \cdot 1 \\
8 \cdot 6\end{array}$ & $\begin{array}{l}25 \cdot 1 \\
11 \cdot 2 \\
10 \cdot 2\end{array}$ & $\begin{array}{r}25.0 \\
10.5 \\
9.8\end{array}$ & $\begin{array}{l}28 \cdot 8 \\
10 \cdot 2 \\
11 \cdot 8\end{array}$ & $\begin{array}{r}22 \cdot 2 \\
9 \cdot 1 \\
8 \cdot 6\end{array}$ & $\begin{array}{r}26.3 \\
9.5 \\
11.6\end{array}$ & $\begin{array}{l}25.1 \\
11.8 \\
10.9\end{array}$ & $\begin{array}{l}31 \cdot 1 \\
11 \cdot 8 \\
12 \cdot 6\end{array}$ \\
\hline 5 & $44 \mathrm{~F}$ & $\begin{array}{l}\mathrm{H} \\
\mathrm{P} \\
\mathrm{B}\end{array}$ & $\begin{array}{r}\gg 100 \\
8 \cdot 7 \\
6 \cdot 2\end{array}$ & $\begin{array}{r}>100 \\
<5 \\
<5\end{array}$ & $\begin{array}{l}31 \cdot 1 \\
<5 \\
<5\end{array}$ & 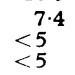 & $\begin{array}{r}\gg 100 \\
8 \cdot 7 \\
6 \cdot 2\end{array}$ & $\begin{array}{r}>100 \\
6.3 \\
5.0\end{array}$ & $\begin{array}{c}>100 \\
<51 \\
<5\end{array}$ & $\begin{array}{l}49 \cdot 8 \\
<5 \\
<5\end{array}$ & $\begin{array}{r}\gg 100 \\
8 \cdot 7 \\
6 \cdot 2\end{array}$ & $\begin{array}{c}>100 \\
7 \cdot 2 \\
<5\end{array}$ & $\begin{array}{c}>100 \\
<5 \\
<5\end{array}$ & $\begin{array}{l}47 \cdot 6 \\
<5 \\
<5\end{array}$ \\
\hline 6 & $75 \mathrm{~F}$ & $\begin{array}{l}\mathrm{H} \\
\mathbf{P} \\
\mathrm{B}\end{array}$ & $\begin{array}{l}31 \cdot 2 \\
23.8 \\
28.6\end{array}$ & $\begin{array}{l}28 \cdot 6 \\
19 \cdot 2 \\
25 \cdot 1\end{array}$ & $\begin{array}{l}22 \cdot 2 \\
15.9 \\
21 \cdot 3\end{array}$ & $\begin{array}{l}13.9 \\
11.9 \\
12.9\end{array}$ & $\begin{array}{l}31.2 \\
23.8 \\
28.6\end{array}$ & $\begin{array}{l}25 \cdot 1 \\
18 \cdot 5 \\
27 \cdot 0\end{array}$ & $\begin{array}{l}22.0 \\
17.4 \\
21.1\end{array}$ & $\begin{array}{l}13.9 \\
12.3 \\
16.4\end{array}$ & $\begin{array}{l}31 \cdot 2 \\
23 \cdot 8 \\
28 \cdot 6\end{array}$ & $\begin{array}{l}27 \cdot 0 \\
19 \cdot 4 \\
24.9\end{array}$ & $\begin{array}{l}23 \cdot 8 \\
16 \cdot 7 \\
21 \cdot 7\end{array}$ & $\begin{array}{l}13 \cdot 9 \\
18 \cdot 2 \\
18 \cdot 2\end{array}$ \\
\hline 7 & $37 \mathrm{~F}$ & $\begin{array}{l}\mathrm{H} \\
\mathrm{P} \\
\mathrm{B}\end{array}$ & $\begin{array}{l}17 \cdot 5 \\
16 \cdot 7 \\
16 \cdot 4\end{array}$ & $\begin{array}{l}20 \cdot 4 \\
16 \cdot 5 \\
16 \cdot 3\end{array}$ & $\begin{array}{l}17 \cdot 9 \\
14.9 \\
14.3\end{array}$ & $\begin{array}{l}9.7 \\
9.7 \\
6.7\end{array}$ & $\begin{array}{l}17.5 \\
16.7 \\
16.4\end{array}$ & $\begin{array}{l}19 \cdot 2 \\
15 \cdot 2 \\
16.6\end{array}$ & $\begin{array}{l}17 \cdot 2 \\
14 \cdot 7 \\
15 \cdot 2\end{array}$ & $\begin{array}{l}9 \cdot 4 \\
8 \cdot 7 \\
7 \cdot 2\end{array}$ & $\begin{array}{l}17.5 \\
16.7 \\
16.4\end{array}$ & $\begin{array}{l}18 \cdot 2 \\
15.2 \\
17.5\end{array}$ & $\begin{array}{l}18 \cdot 3 \\
14.5 \\
16.3\end{array}$ & $\begin{array}{r}12 \cdot 3 \\
9 \cdot 6 \\
10 \cdot 2\end{array}$ \\
\hline 8 & $40 \mathrm{~F}$ & $\begin{array}{l}\mathrm{H} \\
\mathbf{P} \\
\mathrm{B}\end{array}$ & $\begin{array}{l}15 \cdot 4 \\
17 \cdot 2 \\
17 \cdot 9\end{array}$ & $\begin{array}{l}12.5 \\
12.5 \\
18 \cdot 2\end{array}$ & $\begin{array}{l}<5 \\
<5 \\
<5\end{array}$ & $\begin{array}{l}<5 \\
<5 \\
<5\end{array}$ & $\begin{array}{l}15 \cdot 4 \\
17 \cdot 2 \\
17 \cdot 9\end{array}$ & $\begin{array}{l}12.6 \\
12.2 \\
11.6\end{array}$ & $\begin{array}{l}<5 \\
<5 \\
<5\end{array}$ & $\begin{array}{l}<5 \\
<5 \\
<5\end{array}$ & $\begin{array}{l}15 \cdot 4 \\
17 \cdot 2 \\
17.9\end{array}$ & $\begin{array}{l}14 \cdot 1 \\
12 \cdot 5 \\
12 \cdot 0\end{array}$ & $\begin{array}{l}<5 \\
<5 \\
<5\end{array}$ & $\begin{array}{l}<5 \\
<5 \\
<5\end{array}$ \\
\hline 9 & $24 \mathrm{~F}$ & $\begin{array}{l}\mathrm{H} \\
\mathrm{P} \\
\mathrm{B}\end{array}$ & $\begin{array}{l}20.0 \\
21.7 \\
62.5\end{array}$ & $\begin{array}{l}21 \cdot 7 \\
21 \cdot 4 \\
47 \cdot 6\end{array}$ & $\begin{array}{l}19 \cdot 6 \\
20 \cdot 4 \\
40 \cdot 0\end{array}$ & $\begin{array}{l}15 \cdot 4 \\
14 \cdot 9 \\
30 \cdot 1\end{array}$ & $\begin{array}{l}20.0 \\
21 \cdot 7 \\
62.5\end{array}$ & $\begin{array}{l}21.7 \\
21.4 \\
45.5\end{array}$ & $\begin{array}{l}22 \cdot 7 \\
20 \cdot 3 \\
43 \cdot 5\end{array}$ & $\begin{array}{l}15.2 \\
15.4 \\
31 \cdot 3\end{array}$ & $\begin{array}{l}20.0 \\
21.7 \\
62.5\end{array}$ & $\begin{array}{l}24 \cdot 1 \\
23 \cdot 1 \\
45 \cdot 3\end{array}$ & $\begin{array}{l}22 \cdot 2 \\
20 \cdot 8 \\
41 \cdot 7\end{array}$ & $\begin{array}{l}14.5 \\
14.9 \\
27 \cdot 8\end{array}$ \\
\hline $\mathrm{D}_{1}$ & $73 \mathrm{M}$ & $\left\{\begin{array}{l}\mathbf{H} \\
\mathbf{P} \\
\mathbf{B}\end{array}\right.$ & $\begin{array}{l}100 \\
100 \\
100\end{array}$ & $\begin{array}{l}38 \cdot 4 \\
43 \cdot 5 \\
62 \cdot 5\end{array}$ & $\begin{array}{l}18 \cdot 5 \\
20 \cdot 1 \\
26 \cdot 3\end{array}$ & $\begin{array}{r}7 \cdot 7 \\
12 \cdot 8 \\
11 \cdot 8\end{array}$ & $\begin{array}{l}100 \\
100 \\
100\end{array}$ & $\begin{array}{l}34.5 \\
41 \cdot 7 \\
50 \cdot 1\end{array}$ & $\begin{array}{l}18 \cdot 2 \\
23.8 \\
23.8\end{array}$ & $\begin{array}{r}7.7 \\
8.6 \\
11.7\end{array}$ & $\begin{array}{l}100 \\
100 \\
100\end{array}$ & $\begin{array}{l}32.3 \\
52.6 \\
45.4\end{array}$ & $\begin{array}{l}15 \cdot 6 \\
17 \cdot 5 \\
19 ' 2\end{array}$ & $\begin{array}{r}6 \cdot 2 \\
9 \cdot 1 \\
10 \cdot 1\end{array}$ \\
\hline $\mathrm{D}_{2}$ & $42 \mathrm{~F}$ & $\left\{\begin{array}{l}\mathbf{H} \\
\mathbf{P} \\
\mathbf{B}\end{array}\right.$ & $\begin{array}{l}26 \cdot 3 \\
23 \cdot 3 \\
23 \cdot 3\end{array}$ & $\begin{array}{l}20 \cdot 4 \\
16 \cdot 7 \\
19 \cdot 2\end{array}$ & $\begin{array}{r}9 \cdot 1 \\
9.5 \\
12.8\end{array}$ & $\begin{array}{l}<5 \\
<5 \\
7.4\end{array}$ & $\begin{array}{l}26 \cdot 3 \\
23 \cdot 3 \\
23 \cdot 3\end{array}$ & $\begin{array}{l}20 \cdot 5 \\
15 \cdot 2 \\
21 \cdot 3\end{array}$ & $\begin{array}{r}9.1 \\
8 \cdot 7 \\
11.5\end{array}$ & $\begin{array}{r}<5 \\
<5 \\
6.9\end{array}$ & $\begin{array}{l}26 \cdot 3 \\
23 \cdot 3 \\
23 \cdot 3\end{array}$ & $\begin{array}{l}16 \cdot 1 \\
15.3 \\
19 \cdot 2\end{array}$ & $\begin{array}{r}8.8 \\
7.6 \\
10 \cdot 1\end{array}$ & $\begin{array}{r}6.2 \\
<5 \\
\quad 7.4\end{array}$ \\
\hline Norma & ol $(10 M+10 F)$ & $\left\{\begin{array}{l}\mathbf{H} \\
\mathbf{P} \\
\mathbf{B}\end{array}\right.$ & $\begin{array}{l}<5 \\
<5 \\
<5\end{array}$ & $\begin{array}{l}<5 \\
<5 \\
<5\end{array}$ & $\begin{array}{l}<5 \\
<5 \\
<5\end{array}$ & $\begin{array}{l}<5 \\
<5 \\
<5\end{array}$ & $\begin{array}{l}<5 \\
<5 \\
<5\end{array}$ & $\begin{array}{l}<5 \\
<5 \\
<5\end{array}$ & $\begin{array}{l}<5 \\
<5 \\
<5\end{array}$ & $\begin{array}{l}<5 \\
<5 \\
<5\end{array}$ & $\begin{array}{l}<5 \\
<5 \\
<5\end{array}$ & $\begin{array}{l}<5 \\
<5 \\
<5\end{array}$ & $\begin{array}{l}<5 \\
<5 \\
<5\end{array}$ & $\begin{array}{l}<5 \\
<5 \\
<5\end{array}$ \\
\hline
\end{tabular}

\section{DISPLACEMENT STUDIES}

Attempts to inhibit antibody binding immunospecifically were made by adding increasing amounts of "cold" insulin of different species to the incubation mixture so as to obtain final concentrations of $0-1000 \mathrm{U} / \mathrm{l}$. Figure 3 shows the displacemrnt patterns observed and table II gives the full results. Displacement was dose dependent and highly species specific: it occurred only when the species of insulin added was the same as that to which the antibody had been shown to bind on the plate. Thus sera containing antibodies specific against human monocomponent insulin (for example, case 2) were displaceable only by human insulin, even when concentrations of porcine and bovine insulin reaching $1000 \mathrm{U} / 1$ were present. Conversely, sera capable of binding all three insulins (for example, case 6) were displaceable by all three insulins. Serum from case 5 was of particular interest on account of the very close correspondence between its binding and displacement behaviour. It bound strongly to human insulin but weakly to porcine and bovine insulins and was readily displaceable by human but poorly by porcine and bovine insulins.

\section{Discussion}

Doubts have frequently been raised in the past over claims for autoimmunity to insulin, particularly in relation to antibody ${ }^{9}$ or ligand ${ }^{10}$ specificity in the assay and to insulin naivety in the patient. Even in well documented cases, ${ }^{11}$ uncertainty over self administration of insulin must remain; modern insulins contain little if any species marking $\mathrm{C}$ peptide, so that in the absence of $\mathrm{C}$ peptide antibodies it has become exceedingly difficult to distinguish immunologically between induced immunity and autoimmunity.

In the present series, however, none of the nine patients with insulin antibodies was diabetic, all denied contact with insulin, and none had antibodies against animal $\mathrm{C}$ peptide. The assay used did not employ an iodinated ligand and it identified immunoglobulins immunospecifically, effectively ruling out interference from non-immunoglobulin binding factors. The detection of antibodies exclusively against human insulin in sera which were drawn before human insulin was available in Britain tends to remove suspicion of its self administration. Furthermore, all nine patients had independent evidence of autoimmunity, and insulin antibodies were not found in the sera of normal controls, non-insulin dependent diabetics, or patients suspected of autoimmune disease who turned out to be seronegative in tests for their autoimmune profile. Autoimmunity to insulin therefore appears to exist only in the context of polyautoimmunity.

This report points strongly towards the existence of autoimmunity to insulin and suggests that the response may be 
specific for human insulin. Human insulin differs from porcine by a single amino acid substitution, so that a response exclusive to human insulin implies autoantibodies of considerable homogeneity directed against a very limited number of antigenic sites (epitopes). Three important questions arise: How restricted is the clonal response in insulin autoimmunity-might the antibodies be monotypic or even monoclonal? Out of all the possible antigenic sites on an insulin molecule, why is the autoimmune response in more than half of the sera directed against the single or very limited number of epitopes unique to human insulin? Put alternatively, why-apparently against all laws of chance-is the immunoreactive epitope in these responses also the species defining epitope? Finally, what are the clinical implications of our findings?

We are currently studying the clonality of insulin autoantibodies, but it is interesting to note that the autoantibodies found in patients with systemic lupus erythematosus are not only clonally restricted, ${ }^{12}$ but also share the same idiotypes (antigen binding shapes) with unrelated sufferers from the disorder. ${ }^{13}$ Whether the epitopes against which these antibodies respond show evidence of species restriction, similar to that which we have shown in insulin autoimmunity, is unknown.

The trigger for insulin autoantibodies and their role, if any, in the pathogenesis of disease are also unknown, but recent data from virus infected animal models are intriguing. ${ }^{14} 15$ For example, mice infected with passaged reovirus developed insulin dependent diabetes associated with the appearance of antibodies not only against cytoplasmic antigens within the islet cells but also against cell surface antigens and insulin. ${ }^{14}$ The response, furthermore, was polyendocrine, with antibodies against anterior pituitary cells, growth hormone, and thymocytes. ${ }^{15}$ The relation of this viral induced polyendocrine response in animals to the human polyendocrine syndromes, in which multiple autoantibodies are typical ${ }^{1617}$ and from which our test sera were drawn, is likely to provide an area of intense and fruitful study.

TJW was generously supported by the Wellcome Trust and SN by Nordisk-UK and Eli Lilly Co Ltd. We thank Novo Industries (Copenhagen) and Eli Lilly Company (Indianopolis) for their kind gifts of purified insulins and C peptides, Mrs C Casey for technical help, and Mrs L Scott-Morgan for making available the autoimmune sera.

\section{References}

${ }^{1}$ Hirata Y, Ishizu H. Elevated insulin-binding capacity of serum proteins in a case of spontaneous hypoglycaemia and mild diabetes not treated with insulin. Tohuku $\mathcal{F}$ Exp Med 1972;107:277-86.

2 Følling I, Norman N. Hyperglycemia, hypoglycemic attacks, and production of anti-insulin antibodies without previous known immunisation. Diabetes $1972 ; 21: 814-26$

${ }^{3}$ Goldman J, Baldwin D, Rubenstein $\mathrm{AH}$, et al. Characterisation of circulating insulin and pro-insulin binding antibodies in autoimmune hypoglycemia. $\mathcal{F}$ Clin Invest $1979 ; 63: 1050-9$.

4 Palmer JP, Asplin CM, Raghu PK, et al. Anti-insulin antibodies in insulindependent diabetics before insulin treatment-a new marker for autoimmune B-cell damage? Diabetes $1983 ; 32$, suppl 1:76A. (Abstract No 302.)

${ }^{5}$ Reeves WG. Immunology of diabetes and insulin therapy. In: Thompson $\mathrm{RA}$, ed. Recent advances in clinical immunology 2. London and New York: Churchill Livingstone, 1980:183.

6 Tunbridge WMG. Association between autoimmune endocrine diseases. In: Davies TF, ed. Autoimmune endocrine disease. New York: John Wiley and Sons, 1983:98-100.

7 Engvall E, Perlmann P. Enzyme-linked immunosorbent assay, ELISA. $\mathcal{F}$ Immunol 1972;109:129-35.

${ }^{8}$ Ewins DL, Wilkin TJ. A clinical comparison of the enzyme-linked immunosorbent assay (ELISA) and haemagglutination (TRC) in the routine detection of antithyroglobulin antibodies. Acta Endocrinol (Copenh) 1983;103:216-22.

${ }^{9}$ Reeves WG, Kelly U. An immunochemical method for the quantitation of insulin antibodies. F Immunol Methods 1980;34:329-38.

${ }^{10}$ Kuzuya T, Matsuda A, Saito T, Yoshida S. Problems on the specificity of iodinated insulin binding by sera of patients with autoimmune thyroid disorders. Endocrinol fpn 1978;25:597-603.

11 Ohneda A, Matsuda K, Sato M, Yamagata S, Sato T. Hypoglycemia due to apparent autoantibodies to insulin. Diabetes $1974 ; 23: 41-50$.

12 Schwartz RS. Monoclonal lupus antibodies. Immunology Today 1983;4: 68-9.

${ }^{13}$ Solomon G, Schiffenbauer J, Keiser HD, Diamond E. Use of monoclonal antibodies to identify shared idiotypes on human antibodies to native DNA from patients with systemic lupus erythematosus. Proc Natl Acad Sci USA 1983;80:850-4.

14 Onodera T, Toniolo A, Ray UR, Jensen AB, Knazek RA, Notkins AL. Virus induced diabetes mellitus. $\mathcal{F}$ Exp Med 1981;153:1457-73.

15 Onodera T, Ray UR, Melez KA, Suzuki H, Toniolo A, Notkins AL. Virus induced diabetes mellitus: autoimmunity and polyendocrine disease prevented by immunosuppression. Nature $1982 ; 297: 66-8$.

${ }^{16}$ Bottazzo GF, Florin-Christiansen A, Doniach D. Islet cell antibodies in diabetes with autoimmune polyendocrine deficiencies. Lancet 1974; ii : $1279-83$.

${ }^{17}$ Cahill GF, McDevitt HO. Insulin-dependent diabetes mellitus: the initial lesion. $N$ Engl $\mathcal{F}$ Med 1981 ;304:1454-64.

(Accepted 17 November 1983)

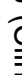

